\title{
THE LIBRARY OF THE ROYAL ARMY MEDICAL COLLEGE
}

\author{
M. DAVIES, Librarian.
}

\section{History}

The present Royal Army Medical College library was founded in 1816 at the York Hospital, Chelsea, largely on the initiative of Sir James McGrigor, the then DirectorGeneral of the Army Medical Department, who presented many of the original books.

In 1860 it was transferred to the Army Medical School at Fort Pitt, Chatham. Three years later the school and library moved to the newly-built Royal Victoria Hospital, Netley, where they remained until the opening of the Royal Army Medical College at Millbank in 1907. These moves and the bombing of the library in World War II resulted in the loss or damage of many of the original volumes.

In 1947 a small room of the library was set aside to be the Muniment Room of the Royal Army Medical Corps Historical Museum Trust, to house its historical books, documents, letters and papers.

It is interesting to note that Regulations for the Army Medical School, (1898) refer to two libraries. Firstly, the Royal Army Medical Corps library, the contents of which were the property of the officers of the Royal Army Medical Corps and which was maintained by their donations and subscriptions: and secondly, the Army Medical School Library, which had been established by the Government for the purpose of assisting the officers attending the Army Medical School: The expenses of this library were defrayed by an annual grant voted in the Army estimates.

The two libraries were in adjoining rooms on the second floor over the main entrance of the Royal Victoria Hospital, Netley.

Since 1907 they have been housed together at Millbank as the library of the Royal Army Medical College.

\section{Functions}

The library is managed by a Committee of the College staff under a chairman appointed by the Commandant of the College, whose approval is required for all purchases and major policy decisions. It contains some 22,000 books and pamphlets and approximately 250 current journals are taken.

The library is available for reference purposes to all officers of the R.A.M.C., and R.A.D.C., and the College staff and its students, including soldiers. It also is available, with the permission of the Commandant, to sponsored research workers, service or civilian.

Books may be borrowed by officers, warrant officers and non-commissioned officers (staff and students) of the Royal Army Medical College and 18 Company, R.A.M.C., by officers, R.A.M.C. and R.A.D.C., serving at the Ministry of Defence and in London District, and by others with the permission of the Commandant.

The librarian can prepare bibliographies and can assist authors preparing articles for publication, for example by the tracing of references. He can also arrange for photocopies to be made of material from books and journals for officers (whether 
Papers presented at the meetings of the Society were published regularly in the Journal of the Royal Army Medical Corps. The last meeting to which any reference can be traced was held on 15th June 1914, and it is assumed that the Society's activities were suspended during the ensuing war years.

On 30th April 1919, the War Section of the Royal Society of Medicine held its first meeting, at which it was suggested that the United Services Medical Society should amalgamate with the Section. A joint meeting took place on 6th June 1919, and the amalgamation went through in the following year. The Section assumed its present title of "United Services" on 19th November 1929.

Editor's note.-My thanks are due to Mrs. E. Coley, Sections Officer of the Royal Söciety of Medicine for her help in enabling me to round off this note.

From the New Year Honours List

Knight Batchelor Mr. E. G. MuIR, M.S., M.B., F.R.C.S. Honorary Consultant in Surgery to the Army and Member of the Army Medical Advisory Board..;

C.B. : : Major-General K. F. StePhens, O.B.E., Q.H.S., M.B., F.F.A.R.C.S.

C.B.E. Colonel W. LEES, T.D., M.B., Ch.B., M.R.C.O.G., D.P.H., T. \& A.V.R. (R.A:R.O.).

O.B.E. Lieutenant-Colonel J. G. MoRAN, L.R.C.P.I. \& L.M., L.R.C.S.I. \& L.M., D.C.H., D.P.H., D.T.M. \& H., R.A.M.C.

M.B.E. : Captain (Q.M.) J. R. Southby, R.A.M.C.

W.O. II C. A. GREen, R.A.M.C., T. \& A.V.R.

B.E.M. $\quad$ S/Sgt J. H. FletCHER, R.A.M.C., T. \&.A.V.R.

\section{ACADEMIC ACHIEVEMENTS}

F.R.C.S.(Eng.)

M.R.C.P.(Iond.)

D.Path.

D.M.R.

F.I.M.L.T,
LIEUTENANT-COLONEL P. j. BOOTH, M.B, B.S., D.L.o., R.A.M.C.

Captain J. E. Findlow, M.B., ch.B., R.a.m.c. Captain J. TaRrant, m.B., B.s., M.R.C.S., L.R.C.P., R.A.M.C.

LieUtenant-Colonel G. VASEY, M.B., B.S., D.T.M. \& H., R.A.M.C.

CAPTAIN B. J. LOVEDAY, M.B., B.S., M.R.C.S., L.R.C..P., R.A.M.C.

LYeutenant L. F. BAKeR, R.A.M.C.

\section{ERRATUM}

Volume 115, No. 4, 1969, page 197.

For D.Phys.Med. against MAJOR C. BOLAND please read D.P.M. 
serving at home or abroad). Such photocopies are supplied on the understanding that copyright is not infringed (i.e. not more than one copy of any article for the sole use of the officer requesting it).

Officers are invited to make proposals to the library committee for the purchase of books or the taking of new journals. Forms for this purpose are obtainable from the librarian.

The librarian has written a short guide to the use of the library which is available from him on request.

REFERENCE

Regulations for the Army Medical School, Netley (1898). pl4. H.M.S.O., London.

\section{An Inter-Service Occasion}

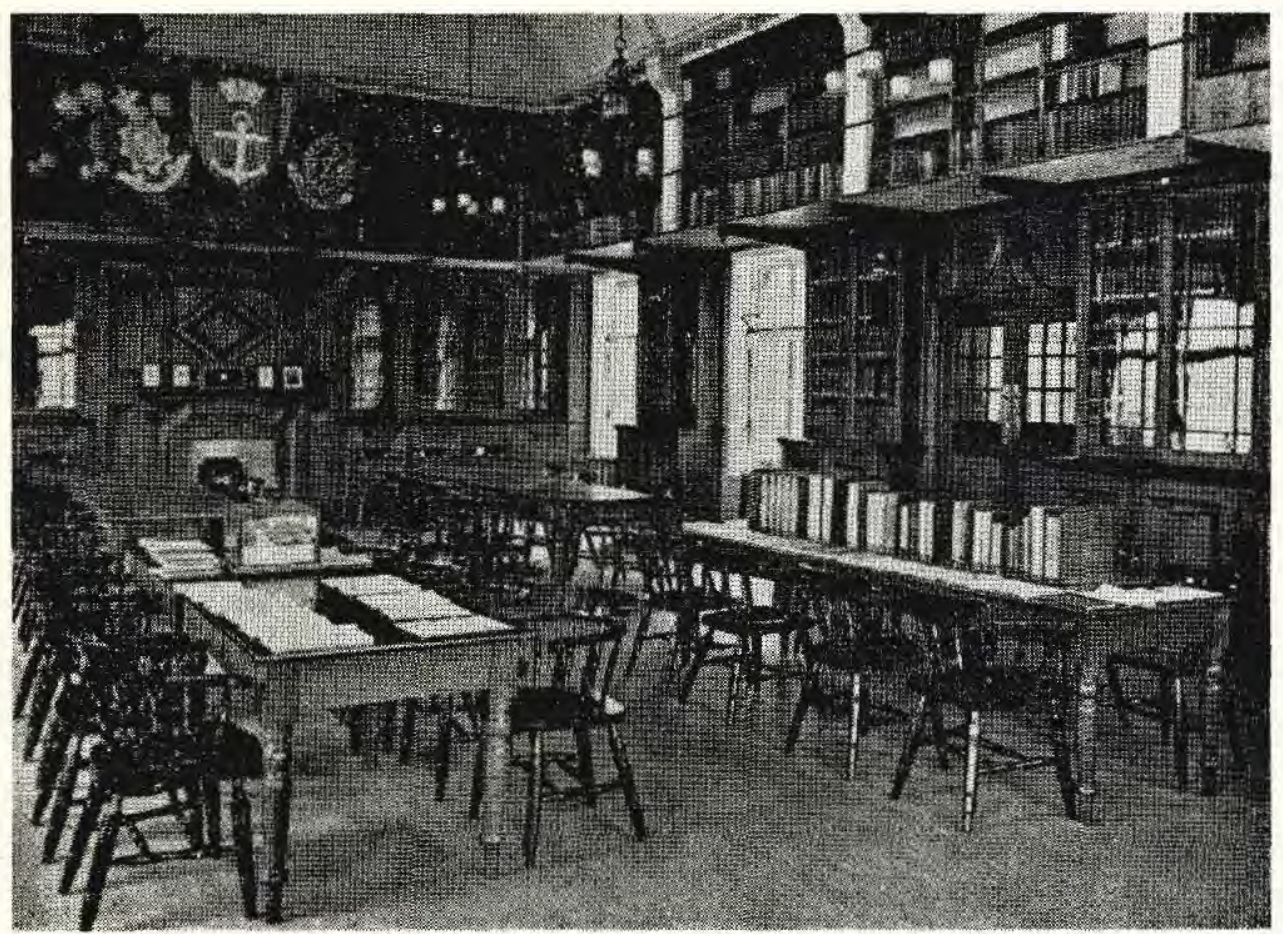

It is believed that this photograph of the Library of the Royal Army Medical College was taken on the occasion of an early meeting of the United Services Medical Society. Membership of the Society was open to all medical officers on the active or retired lists of the Royal Navy, the British and Indian Armies and the Auxiliary and Colonial Forces, the first meeting being held at the College on 10th October 1907. The crests displayed in the background will be recognised $(l$ to $r$ ) as those of the Indian Medical Service, the Royal Navy, and the Royal Army Medical Corps. 